\title{
Hypoglycemic effect of leaf extract of Fimbristylis miliacea in mice model
}

\author{
Sohel $\mathrm{Mia}^{\dagger}$, Roni Roy ${ }^{\dagger}$, Afroza Akter, Md. Abdul Barek and Mohammad Anwarul Basher ${ }^{*}$
}

\begin{abstract}
Hypoglycemic effect of methanol extract of leaf of Fimbristylis miliacea was examined in mice model. Standard drug glibenclamide reduced fasting blood glucose concentration by $46.69 \%$ after $3 \mathrm{~h}$ while extract at $400 \mathrm{mg} / \mathrm{kg}$ showed $36.92 \%$ reduction after same time span. Therefore, it can be concluded that the plant extract is expected to contain phytoconstituent(s) with potential hypoglycemic effect in dextrose-induced hyperglycemic mouse model.
\end{abstract}

\section{Introduction}

Fimbristylis miliacea (L.) Vahl (Cyperaceae) is a widely distributed rice-field weed and found in Bangladesh, India, Pakistan, Cambodia, Laos, Myanmar, Indonesia, Malaysia, central America, west Africa, north Australia, etc. [1, 2]. Several species of Fimbristylis genus are used as herbal medicine such as $F$. miliacea to treat fever, $F$. squarrosa for sore throat, F. falcata in dysentery, $F$. ovata in rheumatism, $F$. umbellaris in splenomegaly, F. pauciflora to induce labour, etc. [3].

Diabetes mellitus is a chronic metabolic disease characterized by abnormalities in carbohydrate metabolism. Insufficient production of insulin and/or increased resistance to insulin causes diabetes. The primary manifestation of the disease is hyperglycemia and it beckons other complications such as hyperlipidemia, hypertension, atherosclerosis, etc. [4]. Oral synthetic hypoglycemic drugs are found therapeutically effective against insulin resistant type 2 diabetes but these drugs also show adverse effects and become ineffective in long-time treatment. Treatment of hyperglycemia with herbal medicines can be considered a pragmatic approach due to availability of plants, low risk of side effects and most importantly low cost of the treatment. Numerous reports have been published reporting potential hypoglycemic effect of plant extracts [5-8]. Therefore, our present study aims to examine hypoglycemic effect of methanol extract of leaf of Fimbristylis miliacea.

\footnotetext{
* Correspondence: m.anwar.basher@gmail.com

'Sohel Mia and Roni Roy contributed equally to this work.

Department of Pharmacy, Noakhali Science and Technology University,

Sonapur, Noakhali 3814, Bangladesh
}

(c) The Author(s). 2019 Open Access This article is distributed under the terms of the Creative Commons Attribution 4.0 International License (http://creativecommons.org/licenses/by/4.0/), which permits unrestricted use, distribution, and reproduction in any medium, provided you give appropriate credit to the original author(s) and the source, provide a link to the Creative Commons license, and indicate if changes were made.

\section{Chemicals and drugs}

Glibenclamide (Square Pharmaceuticals Limited, Bangladesh) was used as standard. Dextrose (Glaxo SmithKline Bangladesh) was used to produce hyperglycemia. Methanol was purchased from local vendor of Merck, Germany.

\section{Animals}

Swiss albino mice (20-25 g) of both sexes were collected from International Centre for Diarrhoeal Disease Research, Bangladesh. Animals were housed in groups of six in each cage $(40 \mathrm{~cm} \times 30 \mathrm{~cm} \times 17 \mathrm{~cm})$ made up of polypropylene base with stainless-steel net. A standard $12 \mathrm{~h}$ light: $12 \mathrm{~h}$ dark cycle was maintained in the animal room having a temperature of $23-25^{\circ} \mathrm{C}$ and relative humidity of $50-55 \%$. Food and water were allowed ad libitum during entire study period.

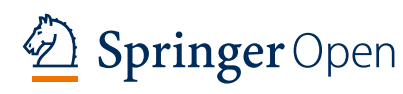




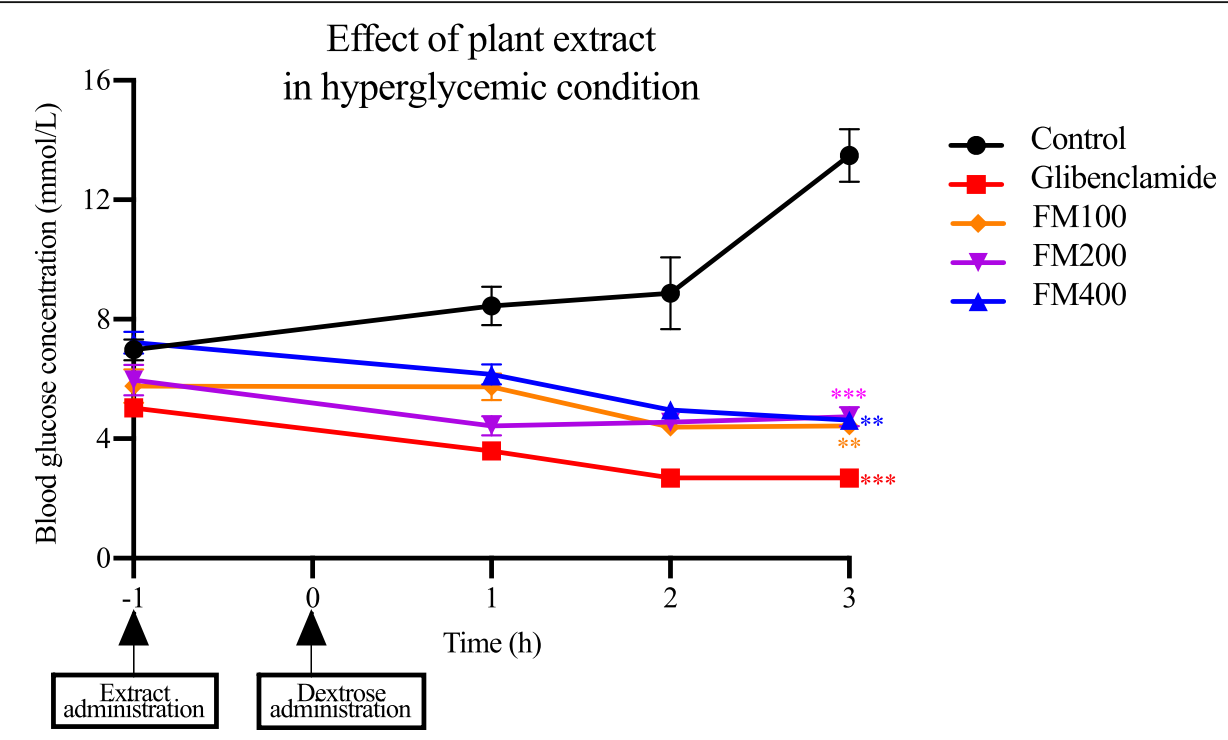

Fig. 1 Effect of methanol leaf extract of Fimbristylis miliacea on hyperglycemic condition. 'FM' stands for Fimbristylis miliacea and 100, 200 and 300 indicate doses in $\mathrm{mg} / \mathrm{kg}$. A probability level of 0.05 or less was accepted as significant; ${ }^{*} p<0.05,{ }^{* *} p<0.01,{ }^{* * *} p<0.001$ vs. control i.e. distilled water

\section{Experimental procedures}

Hypoglycemic effect of leaf extract in mice model was performed according the method described by Joy and Kuttan (1999) [9]. A group of six mice was used for each test sample. For Group I (control), mice were given only distilled water $(10 \mathrm{~mL} / \mathrm{kg}$ of mouse body weight) while Group II was used as standard group and treated with glibenclamide $(10 \mathrm{mg} / \mathrm{kg})$. Group III, IV and V were treated with leaf extract at doses of $100 \mathrm{mg} / \mathrm{kg}, 200 \mathrm{mg} / \mathrm{kg}$ and $400 \mathrm{mg} / \mathrm{kg}$ of mouse body weight respectively. All animals were fasted overnight before the experiment. The experiment was started by measuring blood glucose concentration (fasting glucose concentration) followed by immediate administration (p.o.) of test sample to respective group and then rested for next $1 \mathrm{~h}$. After this period, dextrose $(2 \mathrm{~g} / \mathrm{kg})$ solution was administered to all groups. Blood was collected from mouse tail vein after $1 \mathrm{~h}, 2 \mathrm{~h}$ and $3 \mathrm{~h}$ of glucose administration. Glucose concentration was measured by Accu-Check electronic glucometer (Roche, Germany).

\section{Statistical analysis}

Data were calculated as mean \pm SEM values. One-way ANOVA with Dunnett's test was done using GraphPad
Prism (version 8.0). A probability level of 0.05 or less was accepted as significant; " $p<0.05, \quad p<0.01, \quad p<$ 0.001 vs. control. Percentage reduction in glucose concentration was calculated as (fasting glucose concentration - glucose concentration at specific time point) $x$ 100/fasting glucose concentration.

\section{Results and discussion}

Effect of methanol leaf extract on hyperglycemia is shown in Fig. 1 and Table 1. Leaf extract at all doses showed significant reduction $(p<0.01$ for $100 \mathrm{mg} / \mathrm{kg}$, $p<0.001$ for $200 \mathrm{mg} / \mathrm{kg}$ and $\mathrm{p}<0.01$ for $400 \mathrm{mg} / \mathrm{kg}$ ) in blood glucose concentration. Extract at $400 \mathrm{mg} / \mathrm{kg}$ produced time-dependent effect that gradually increased as time elapsed; similar phenomenon was observed for 100 $\mathrm{mg} / \mathrm{kg}$ dose. Extract at doses of $200 \mathrm{mg} / \mathrm{kg}$ showed prompt effect at $1 \mathrm{~h}$ but effect was slightly reduced over time. Maximum hypoglycemic effect (36.92\%) was observed at $400 \mathrm{mg} / \mathrm{kg}$ extract after $3 \mathrm{~h}$ while glibenclamide produced $46.69 \%$ reduction.

Different plant extracts of diverse genera and families have been reported to show hypoglycemic effect due to the presence of various classes of phytoconstituents such

Table 1 Percentage reduction of blood glucose concentration by methanolic extract of leaf of Fimbristylis miliacea

\begin{tabular}{|c|c|c|c|}
\hline & \multicolumn{3}{|c|}{ Reduction of blood glucose concentration (from fasting glucose concentration) } \\
\hline & After $1 \mathrm{~h}$ & After $2 \mathrm{~h}$ & After $3 \mathrm{~h}$ \\
\hline Glibenclamide & $28.47 \%$ & $46.69 \%$ & $46.69 \%$ \\
\hline FM100 & $0.59 \%$ & $23.70 \%$ & $24.87 \%$ \\
\hline FM200 & $25.70 \%$ & $23.74 \%$ & $20.68 \%$ \\
\hline FM400 & $14.78 \%$ & $31.18 \%$ & $36.92 \%$ \\
\hline
\end{tabular}

'FM' stands for Fimbristylis miliacea and 100, 200 and 400 indicate doses in mg/kg 
as terpenoids [10], alkaloids [11], flavonoids [12], glycosides [13], etc. Hypoglycemic effect of plant extracts may be due to stimulation of insulin release by $\beta$-cells or inhibition of glucose absorption from intestine. Leaf extract of Fimbristylis miliacea is expected to contain important phytoconstituents that offer potent hypoglycemic effect. Further phytochemical and biological investigations are required to isolate one or more phytoconstituent responsible for hypoglycemic effect with mechanism of action.

\section{Abbreviations}

g: Gram; h: Hour; mg: Milligram; SEM: Standard error mean

\section{Acknowledgments}

Not applicable.

\section{Authors' contributions}

$S M$ and RR equally participated in the conduction of the experiments. RR, AA and $M A B$ did the initial literature search and assisted animal handling. SM, $\mathrm{RR}, \mathrm{AA}$ and MAB participated in preparing the manuscript and MA Basher designed the concept, analyzed the data and revised the manuscript. All authors read and approved the final manuscript.

\section{Funding}

The research work was partially funded by the institution from research

allocations for Master's students.

\section{Availability of data and materials}

The datasets used and/or analyzed during the current study are available

from the corresponding author on reasonable request.

Ethics approval and consent to participate

The animal experiment performed in this study was approved by the

Departmental Ethics Committee.

\section{Consent for publication}

Not applicable.

\section{Competing interests}

All authors declared that they have no competing interests.

Received: 15 April 2019 Accepted: 17 July 2019

Published online: 30 July 2019

References

1. Moody K. Weeds reported to occur in rice in south and Southeast Asia. Los Baños, Laguna, Phillipines: International Rice Research Institute; 1989

2. Waterhouse DF. Biological control of weeds: southeast Asian prospects. The Australian Centre for Intemational Agricultural Research: Canberra, Australia; 1994. $271 \mathrm{p}$

3. Simpson DA, Inglis CA. Cyperaceae of economic, ethnobotanical and horticultural importance: a checklist. Kew Bull. 2001;56(2):257-360.

4. DeFronzo RA, Bonadonna RC, Ferrannini E. Pathogenesis of NIDDM: a balanced overview. Diabetes Care. 1992;15(3):318-68.

5. Ali L, Khan AKA, Mamun MIR, Mosihuzzaman M, Nahar N, Nur-E-Alam M, et al. Studies on hypoglycemic effects of fruit pulp, seed, and whole plant of Momordica charantia on normal and diabetic model rats. Planta Med. 1993;59(05):408-12.

6. Aybar MJ, Riera ANS, Grau A, Sanchez SS. Hypoglycemic effect of the water extract of Smallantus sonchifolius (yacon) leaves in normal and diabetic rats. J Ethnopharmacol. 2001;74(2):125-32.

7. Luo Q, Cai Y, Yan J, Sun M, Corke H. Hypoglycemic and hypolipidemic effects and antioxidant activity of fruit extracts from Lycium barbarum. Life Sci. 2004:76(2):137-49.

8. Hasan MN, Rahman MH, Guo R, Hirashima A. Hypoglycemic activity of methanolic leaf extract of Blumea lacera in Swiss-albino mice. Asian Pac J Trop Dis. 2015;5(3)
9. Joy K, Kuttan R. Anti-diabetic activity of Picrorrhiza kurroa extract. J Ethnopharmacol. 1999:67(2):143-8.

10. Uddin N, Hasan MR, Hossain MM, Sarker A, Hasan AN, Islam AM, et al. In vitro aamylase inhibitory activity and in vivo hypoglycemic effect of methanol extract of Citrus macroptera Montr. Fruit. Asian Pac J Trop Biomed. 2014;4(6):473-9.

11. Patel MB, Mishra S. Hypoglycemic activity of alkaloidal fraction of Tinospora cordifolia. Phytomedicine. 2011;18(12):1045-52.

12. Lü H, Chen J, Li W, Ren B, Wu J, Zhang H. Hypoglycemic effect of the total flavonoid fraction from Folium Eriobotryae. Phytomedicine. 2009;16(10):967-71.

13. Chen J, Li W, Wu J, Ren B, Zhang H. Hypoglycemic effects of a

sesquiterpene glycoside isolated from leaves of loquat (Eriobotrya japonica (Thunb.) Lindl.). Phytomedicine. 2008;15(1-2):98-102.

\section{Publisher's Note}

Springer Nature remains neutral with regard to jurisdictional claims in published maps and institutional affiliations.

\section{Submit your manuscript to a SpringerOpen ${ }^{\circ}$ journal and benefit from:}

- Convenient online submission

- Rigorous peer review

- Open access: articles freely available online

- High visibility within the field

- Retaining the copyright to your article

Submit your next manuscript at $>$ springeropen.com 